\title{
Assessing Risk and Sources of Heavy Metals in a Tropical River Basin: A Case Study of the Selangor River, Malaysia
}

\author{
Faridah Othman $^{1 *}$, Md. Sadek Uddin Chowdhury ${ }^{1}$, Wan Zurina Wan Jaafar', \\ E.M. Mohammad Faresh ${ }^{1}$, S.M. Shirazi ${ }^{2}$ \\ ${ }^{1}$ Civil Engineering Deptartment, Faculty of Engineering, University of Malaya, 50603 Kuala Lumpur, Malaysia \\ ${ }^{2}$ Department of Civil Engineering, World University of Bangladesh, , Dhaka 1205, Bangladesh
}

Received: 19 May 2017

Accepted: 6 August 2017

\begin{abstract}
Heavy metal concentration has become a major concern for water quality in rivers. Rapid urbanization and industrialization contribute to heavy metal concentrations in river water. This study aims to investigate the distribution, source, and environmental risk of heavy metals in the Selangor River basin in Malaysia. A total of 132 water samples were collected from 11 sampling stations on a monthly basis over a one-year period. Thirteen heavy metals were analyzed using inductively coupled plasma optical emission spectroscopy (ICP-OES). In order to identify the sources of heavy metals along the river basin, multivariate statistical techniques like principal component analysis (PCA) and cluster analysis (CA) were performed. It was found that As, Mn, and Fe exceeded the admissible limits of the Malaysian National Standard Water Quality (NSDWQ) at several of the sampling stations. Heavy metal pollution index (HPI) was below the critical pollution index value of 100. Statistical analyses showed that potential sources of heavy metals are land-based, thereby implying that former tin mining and industries in the surrounding area are the most likely sources. Anthropogenic metal concentrations were found to be low in the Selangor River, indicating that it has yet to be burdened by pollution of heavy metals.
\end{abstract}

Keywords: heavy metals, Selangor River, pollution, water quality

\section{Introduction}

The contamination of natural environment components such as soil, sediment, water resources, and biota by heavy metals is one of the major concerns impacting environmental problems worldwide because these metals are indestructible. Furthermore, most of them are toxic to living organisms when they exceed

*e-mail: faridahothman@um.edu.my certain concentrations [1]. The sources of environmental anthropogenic pollution by heavy metals include a variety of establishments, namely the agricultural and power industries, the transportation sector, and municipal waste management facilities [2]. Heavy metals are introduced into rivers and waterways through surface runoff and industrial effluent. The increasing tendency of heavy metal concentrations in the environment has caused great concerns globally [3].

Water bodies may consistently hold anthropogenic metals that can ultimately be transferred to humans 
through the food chain. Some of the heavy metals such as copper $(\mathrm{Cu})$, zinc $(\mathrm{Zn})$, iron $(\mathrm{Fe})$, manganese $(\mathrm{Mn})$, and nickel (Ni) are vital for aquatic biological systems to function optimally. However, excessive concentrations can be toxic to living organisms. Heavy metal contaminants such as chromium $(\mathrm{Cr})$, nickel $(\mathrm{Ni})$, copper $(\mathrm{Cu})$, zinc $(\mathrm{Zn})$, cadmium $(\mathrm{Cd})$, and lead $(\mathrm{Pb})$ are generally more persistent than organic contaminants [4]. Metal nutritional requirements vary substantially among animals or plant species and also differ with a range of element types [5]. Both industrial and urbanization activities have greatly increased the heavy metal burden on the environment [6].

Recent reports of elevated total dissolved metal levels in aquatic environments have attracted worldwide attention [7-11]. Previous studies [12-14] have reported that some Malaysian rivers are contaminated with $\mathrm{Ag}$, $\mathrm{As}, \mathrm{Cd}, \mathrm{Cu}, \mathrm{Pb}$, and $\mathrm{Zn}$, while certain coastal sediments are contaminated with $\mathrm{Cd}, \mathrm{Pb}$, and $\mathrm{Zn}$. The Selangor River basin in Malaysia functions as the primary water source for Selangor and Kuala Lumpur [15] for domestic, industrial, and irrigational purposes. Rapid urbanization and industrialization, and thus increasing number of STPs, wet markets, mining activities, and agricultural activities have negatively impacted the Selangor River and its associated ecosystems. Eleven industrial estates have reportedly discharged mineral micro-pollutants (As, B, Cd, Cr, Cu, Hg, Ni, Pb, Sn, and Zn) and mineral pollutants ( $\mathrm{Fe}$ and $\mathrm{Mn}$ ) with metal loads of 181.4 and $912 \mathrm{~kg} /$ day, respectively [16]. Large amounts of uncontrolled metal inputs from industrial sources have contributed to increased river pollution [17].
Due to rapid urbanization and industrialization, the water bodies of the Selangor River basin have unfortunately been polluted with heavy metals. To date, no studies have assessed the risks and sources of heavy metals in this river basin. Thus it is timely and necessary to evaluate the ecological risks of heavy metals in order to identify and control probable sources of pollution in the environment [18].

Thus, the objectives of the present study are threepronged: 1) evaluate the concentrations of certain heavy metals in the Selangor River basin before comparing them against the recommended standards set by the Malaysian National Water Quality Standard (NWQS) and the Ministry of Health (MOH), 2) characterize and correlate heavy metals by statistical analysis, and 3) assess the risks of heavy metals as contaminants based on the heavy metal pollution index (HPI). These will assist relevant authorities and decision makers in identifying the spatial levels and reasons for water quality problems, such as land use practices and their ensuing effects on the waterways throughout the Selangor River basin.

\section{Materials and Methods}

\section{Study Area}

The Selangor River basin is located within Selangor State of Malaysia. Its catchment area is approximately 2,200 $\mathrm{km}^{2}$ wide, which makes up nearly a quarter of the total area of Selangor. The basin is located to the north of Kuala Lumpur, bound by the Klang basin in the south and

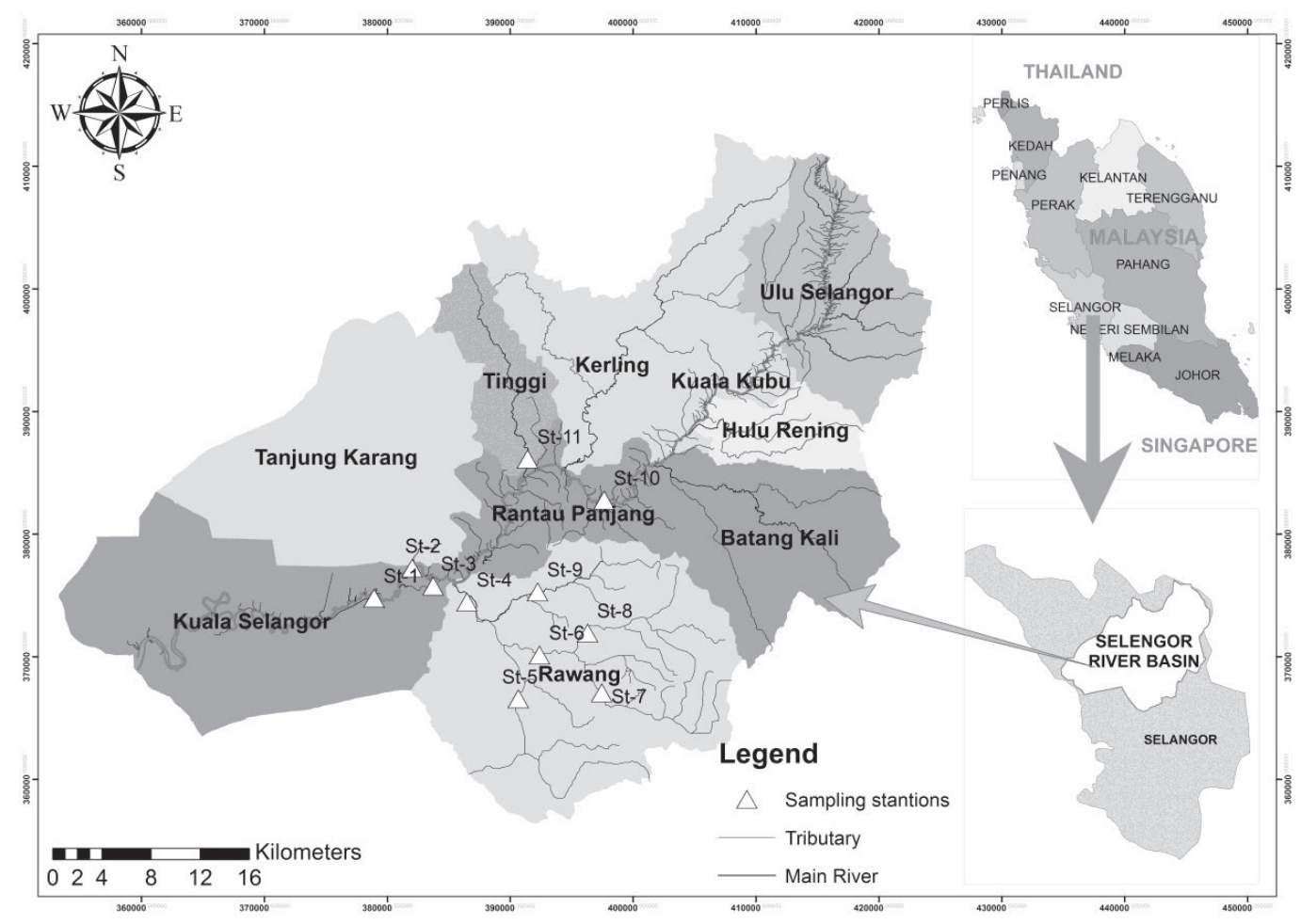

Fig. 1. Map of Selangor River basin with sub-basins and sampling stations. 
the Bernam basin in the north; encompassing the Gombak, Kuala Selangor, and Hulu Selangor districts. The Selangor River flows in a southwesterly direction, traversing a total distance of about $110 \mathrm{~km}$ before eventually discharging into the Straits of Malacca. Its main tributaries cover large areas of Batang Kali, Serendah, Buloh, Kerling, Sembah, Kundang, and Rawang. The typical rainy season, i.e., the northern monsoon, usually runs from October to April, whereas the dry season, i.e., the southern monsoon, is from May to September. The basin is divided into $10 \mathrm{sub}-$ basins based on hydrological boundaries (Fig. 1), which easily demarcate the hilly parts of the basin. However, in the flat coastal plains, it is rather more difficult to be distinguished. This is the case for the peat swamp forests, where the hydrology is little known, and also for the lowlying coastal flat areas where the natural drainage pattern has been altered by agricultural drainage.

The basin is still a largely rural catchment, predominantly utilized for forestry and agriculture. About $57 \%$ of the basin is still covered by natural forests. This includes a forest reserve catchment for Selangor Dam in the northeast and swampy forests in the mid and lowlying regions. Agricultural activities occupy another 23\% of the basin area. These principally include rubber estates and oil palm plantations. Some paddy fields are found in the low-lying coastal areas. The land use map of Selangor River basin is shown in Fig. 6. Selangor has the largest built-up area among the states of Malaysia [19]. About $80 \%$ of its built-up areas are located in the Rawang subbasin, which is the most developed and densely populated area within the Selangor River basin. Not surprisingly, this is where a lot of point and non-point sources are

Table 1. Characteristics of the sampling stations.

\begin{tabular}{|c|c|c|}
\hline Stations & River name & Major activity \\
\hline St-1 & Selangor & Close to sanitary landfill \\
\hline Ayer Hitam & $\begin{array}{c}\text { Former tin-mining catchment, } \\
\text { peatland in the surrounding area } \\
\text { and palm oil plantations, palm } \\
\text { oil factories }\end{array}$ \\
\hline St-3 & Selangor & Sand mining \\
\hline St-5 & Kuang & $\begin{array}{c}\text { Industry effluent and former tin- } \\
\text { mining catchment }\end{array}$ \\
\hline St-6 & Gong & $\begin{array}{c}\text { Industry effluent, wastewa- } \\
\text { ter from restaurants and wet } \\
\text { markets, and former tin-mining } \\
\text { catchment }\end{array}$ \\
\hline St-7 & Rawang & Industrial effluent \\
\hline St-8 & Serendah & Residential wastewater \\
\hline St-9 & Guntong & Residential wastewater \\
\hline St-10 & Selangor & Agricultural activities \\
\hline St-11 & Buloh & Residential wastewater \\
\hline
\end{tabular}

generated from surrounding industries and urbanization activities.

\section{Sampling}

Eleven sampling stations were selected to assess the metal concentrations along the Selangor River and its tributaries. The selected stations are believed to be ideally located to represent the encompassing areas of the Selangor River basin, as shown in Fig. 1. A description of the 11 sampling stations are provided in Table 1 . Sampling stations St-4, 5, 6, 7, 8, and 9 are located in the Rawang sub-basin, which is the most populated, urbanized, and industrialized area. Station St-1 is located a little bit downstream, while station St-11 is upstream of the river basin. Meanwhile, station St-2 is situated in the former tin mining catchment area of Bestari Jaya. Water samples were collected monthly over a 12-month period from October 2013 to September 2014. The International Organization for Standardization (ISO 1985) protocol was followed for sample handling and preservation. Each sample was collected 09:00-17:00. All field samples were kept in a cool room below $4^{\circ} \mathrm{C}$ to reduce any activity and metabolism of aquatic organisms.

\section{In-situ Analysis}

The chemical and physical variables that were measured directly at each sampling station include temperature, dissolved oxygen (DO), conductivity, $\mathrm{pH}$, total dissolved solid (TDS), turbidity, and salinity. Temperature, DO, EC, TDS, salinity, and $\mathrm{pH}$ were measured by a handheld multi-parameter instrument (YSI, Inc.) and turbidity was measured by a Turbidity meter 2100P (HACH, Inc.). The equipment was calibrated prior to use based on the manufacturer's directions. GPS (global positioning system) was used to record the sampling stations' coordinates and directions. With the recorded GPS coordinates the sampling station locations were identified on the geographic information system (GIS) base map. ArcGIS version 10.1 was used to develop the GIS map.

\section{Laboratory Analysis}

Sample preparations were prepared in line with USEPA 200.7. Twenty $\mathrm{ml}$ of each sample were dispensed into a $50 \mathrm{ml}$ centrifuge tube. Then $0.4 \mathrm{ml}$ of nitric acid $(1+1)$ was dispensed into the samples. The centrifuge tubes were placed in a water bath at $85^{\circ} \mathrm{C}$ for two hours [19]. Afterward the centrifuge tubes were removed from the water bath and the solution was cooled to room temperature. The water samples were then filtered through a $0.45 \mu \mathrm{m}$ cellulose acetate membrane filter using a syringe filtration unit. Dissolved metal from samples which could clog the spectrometer during analysis was sifted out by filtration. A quality control sample was also prepared to check the recovery as per the USEPA-2010 guideline. The reproducibility and recovery of the metal 
Table 2. In situ analysis results.

\begin{tabular}{|c|c|c|c|c|c|c|c|c|c|c|c|c|c|c|c|}
\hline \multirow{2}{*}{ Sampling Site } & \multicolumn{3}{|c|}{$\begin{array}{l}\mathrm{pH} \\
(-)\end{array}$} & \multicolumn{3}{|c|}{$\begin{array}{c}\mathrm{EC} \\
(\mu \mathrm{s} / \mathrm{cm})\end{array}$} & \multicolumn{3}{|c|}{$\begin{array}{c}\text { Temperature } \\
\left({ }^{\circ} \mathrm{C}\right)\end{array}$} & \multicolumn{3}{|c|}{$\begin{array}{l}\text { Turbidity } \\
\text { (NTU) }\end{array}$} & \multicolumn{3}{|c|}{$\begin{array}{c}\mathrm{DO} \\
(\mathrm{mg} / \mathrm{L})\end{array}$} \\
\hline & Avg & $\operatorname{Max}$ & Min & Avg & Max & Min & Avg & Max & Min & Avg & Max & Min & Avg & Max & Min \\
\hline St-1 & 6.6 & 7.3 & 6.08 & 61.5 & 101.0 & 34.0 & 28.4 & 31.3 & 26.3 & 173.1 & 891.0 & 46.7 & 5.5 & 6.3 & 4.1 \\
\hline St-2 & 6.0 & 7.4 & 5.01 & 72.2 & 160.0 & 34.0 & 29.3 & 31.8 & 26.0 & 145.9 & 380.0 & 63.0 & 3.9 & 4.8 & 3.2 \\
\hline St-3 & 6.7 & 7.5 & 6.13 & 56.8 & 82.0 & 51.0 & 28.9 & 31.7 & 26.3 & 222.9 & 832.0 & 49.0 & 5.1 & 5.8 & 3.9 \\
\hline St-4 & 6.9 & 7.6 & 6.33 & 142.7 & 191.0 & 121.0 & 29.6 & 31.8 & 28.2 & 390.1 & $1,485.0$ & 67.6 & 3.8 & 5.6 & 2.7 \\
\hline St-5 & 6.9 & 7.5 & 6.21 & 127.0 & 290.0 & 33.0 & 29.8 & 32.2 & 28.4 & 950.5 & $3,570.0$ & 52.0 & 3.1 & 4.9 & 1.9 \\
\hline St-6 & 6.9 & 7.5 & 6.47 & 119.7 & 297.0 & 21.0 & 31.2 & 33.6 & 29.6 & 42.1 & 113.0 & 22.5 & 2.6 & 3.9 & 1.3 \\
\hline St-7 & 7.3 & 8.4 & 6.46 & 141.1 & 194.0 & 125.0 & 30.8 & 33.6 & 28.4 & 196.7 & 706.0 & 51.7 & 4.7 & 6.0 & 2.7 \\
\hline St-8 & 7.1 & 7.9 & 6.33 & 67.6 & 91.0 & 45.0 & 30.8 & 33.3 & 28.2 & 148.3 & $1,288.0$ & 10.8 & 6.7 & 7.9 & 5.5 \\
\hline St-9 & 6.8 & 7.59 & 5.3 & 116.7 & 284.0 & 28.0 & 31.3 & 33.7 & 27.7 & 201.2 & $1,114.0$ & 7.0 & 5.9 & 6.8 & 4.2 \\
\hline St-10 & 6.8 & 7.3 & 6.1 & 41.8 & 72.0 & 14.0 & 29.6 & 32.2 & 27.5 & 43.6 & 116.0 & 13.7 & 7.1 & 8.0 & 6.0 \\
\hline St-11 & 6.2 & 6.74 & 5.7 & 21.4 & 34.0 & 13.0 & 31.5 & 33.4 & 28.7 & 28.6 & 68.0 & 10.1 & 6.3 & 7.2 & 5.3 \\
\hline
\end{tabular}

analysis in the water samples spiked with appropriate metal amounts.

\section{Analytical Determination of Metals}

The prepared samples were analyzed for most metal concentrations using ICP-OES. For this water quality evaluation we found the total dissolved elements and major ion concentrations viz. $\mathrm{As}, \mathrm{Cd}, \mathrm{Co}, \mathrm{Cr}, \mathrm{Cu}, \mathrm{Ni}, \mathrm{Pb}, \mathrm{Fe}, \mathrm{Al}$, $\mathrm{Mg}, \mathrm{Zn}$, and $\mathrm{Mn}$. ICP multi-element standard solution IV Certipur and arsenic standard solution traceable to SRM from NIST $\mathrm{H}_{3} \mathrm{ASO}_{4}$ in $\mathrm{HNO}_{3} 0.5 \mathrm{MOL} / \mathrm{L} 1000 \mathrm{MG} / \mathrm{L}$ as CertiPur were used as standard solution. Five standards were analyzed in order to float the calibration curves. The wavelengths of each element and their corresponding limit of detection (LOD), including the quantitative limits, are listed in Table 3.

\section{Statistical Data Analysis}

For best characterization of the heavy metals we applied data statistical techniques like box and whisker plots, correlation analysis (CA), principal component analysis (PCA), and agglomerative hierarchal cluster analysis (AHCA. The results of heavy metals concentration of each station were distributed by box and whisker plots. Correlations between metals were analyzed by Pearson's correlation coefficients. The main reason for using PCA is the data reduction in order to better represent the relationship between the variables well. Cluster analysis was done for identifying relatively homogeneous groups of variables based on their similarities. In the agglomerative hierarchal cluster method each variable first forms a separate cluster, which combines repeatedly until all the variables come under a single cluster. SPSS 22 was used for box and whisker plots, PCA, and AHCA.

\section{Hierarchical Cluster Analysis}

The result of HCA can be displayed graphically using the tree diagram, also known as a dendrogram. A dendrogram distinguishes groups of high similarity that have small distances between clusters while the dissimilarity between groups is represented by the maximum of all possible distances between clusters. It is a useful technique for investigating spatial and temporal variations [21]. HCA was performed on the heavy metals data in order to investigate the groupings of the sampling station within the Selangor River basin.

\section{Principal Component Analysis}

PCA is an exploratory, multivariate, statistical technique that can be used to examine data variability [22]. The main reason for using PCA is to explain the variance-covariance structure of a set of variables through linear combinations. In this study components were selected in such a way that the first PC explains most of the variance in the data, and each subsequent one accounts for the largest proportion of variability that has not been accounted for by its predecessors. This was performed to clearly define the potential factors or metals sources contributing more to the variation of Selangor River water quality.

\section{Heavy Metal Pollution Index}

Environmental risk assessment was conducted by comparing the HPI within the study area. The HPI was calculated using the following equation [23] as depicted in Equation (1):

$$
H P I=\sum Q_{i} W_{i}
$$


...where $W_{i}$ is the rating or unit weightage for each parameter selected for heavy metal evaluation and is inversely proportional to the recommended standard, i.e., the highest permissible value for the drinking water $\left(S_{i}\right)$ of the heavy metals. The rating is a value between zero and one. $Q_{i}$ is the Subindex of the $i_{t h}$ parameter and was calculated using Equation (2):

$$
Q_{i}=\frac{\left(M_{i}-I_{i}\right)}{\left(s_{i}-I_{i}\right)} \times 100
$$

...where $M_{i}$ is the observed value of the $i_{\text {th }}$ parameter, $I_{i}$ is the maximum desirable value (ideal) of the $i_{t h}$ parameter, and $S_{i}$ is the recommended standard of the $i_{t h}$ parameter. The critical pollution index value is taken to be 100 . For the present study the $S_{i}$ and $I_{i}$ values were taken from the Malaysian national water quality standard.

\section{Results and Discussions}

\section{In-situ Results}

The in-situ analysis results are summarized in Table 2. The lowest value of $\mathrm{pH}$ was detected at St-2. On account of the peat land surrounding the Air Hitam River, the $\mathrm{pH}$ value at sampling station St-2 was low. The electrical conductivity (EC) result represents the amount of dissolved inorganic ions in water, which is also considered to be one of the important parameters in water quality. The EC results of the study were well below standard limits. According to [24], if the EC value exceeded $1,000 \mu \mathrm{S} / \mathrm{cm}$, then the river is exposed to pollution. The temperature of water was almost stable and in the normal range. Highest turbidity was recorded at St-5 while lowest dissolve oxygen (DO) was measured at St-6. Overall, in-situ results indicated that St- 2, 4, 5, 6, 7, and 9 are more polluted than other stations. St- 4, 5, 6, 7, and 9 are within the Rawang sub-basin. A comparison with NWQS indicates that at all sampling stations the temperature lies within the normal range, $\mathrm{pH}$ is class II, electric conductivity falls in class III, dissolved oxygen is class III, and turbidity is class III.

\section{Analytical Results of Heavy Metals Concentrations}

Table 3 presents the recovery of the analytical procedure of heavy metal analysis. The recovery of the procedure for water samples metal analysis was within the range of $80-120 \%$ for all metals. This implies that the extraction procedure used was for acid-soluble metal compounds from river water (U.S. EPA Method 200.7). The analysis of seven replicates of each water sample demonstrated relative standard errors (RSD) below 10\% in general (USEPA-2010).

The descriptive statistics of heavy metals are summarized in Table 4. Standard deviation (SD) and coefficient of variance $(\mathrm{CV})$ are statistical measurements of dispersion in a data series around its average, and the $\mathrm{CV}$ denotes the ratio of standard deviation to the metals concentration. As shown in Table 4, the average concentrations of $\mathrm{As}, \mathrm{Fe}$, and $\mathrm{Mn}$ exceeded the limit of the NSDWQ and the standard proposed by the MOH [25]. The other metals had average concentrations that were less than the standards. The mean and maximum value of Fe crossed both limits. The average concentration of $\mathrm{Mn}$ is below the MOH and NSWQS limit; however the maximum value of $\mathrm{Mn}$ exceeded both limits. The mean value of As exceeded the $\mathrm{MOH}$ limit but was below the

Table 3. Percentage recovery of metals for water analysis by ICP-OES.

\begin{tabular}{|c|c|c|c|c|c|}
\hline Metals & $\begin{array}{c}\text { Wavelength } \\
(\mathrm{nm})\end{array}$ & $\begin{array}{c}\text { Detection limit } \\
\text { ranges }(\mu \mathrm{g} / \mathrm{L})\end{array}$ & $\begin{array}{c}\text { Quantitative limits } \\
(\mu \mathrm{g} / \mathrm{L})\end{array}$ & $\begin{array}{c}\text { Calibration } \\
\text { curve }(\mathrm{r})\end{array}$ & $\begin{array}{c}\text { Recovery } \\
(\%)\end{array}$ \\
\hline $\mathrm{Ag}$ & 328.068 & 0.17 & 0.57 & 0.9998 & 98.10 \\
\hline $\mathrm{As}$ & 188.979 & 0.97 & 3.27 & 0.9922 & 83.47 \\
\hline $\mathrm{Cd}$ & 228.802 & 0.39 & 1.30 & 0.9999 & 86.12 \\
\hline $\mathrm{Co}$ & 228.616 & 0.21 & 0.70 & 0.9997 & 88.72 \\
\hline $\mathrm{Cr}$ & 262.716 & 0.12 & 0.40 & 0.9999 & 91.46 \\
\hline $\mathrm{Cu}$ & 327.393 & 0.48 & 1.60 & 0.9998 & 100.47 \\
\hline $\mathrm{Pb}$ & 220.353 & 1.20 & 4.00 & 0.9993 & 89.13 \\
\hline $\mathrm{Ni}$ & 231.604 & 0.21 & 0.70 & 0.9992 & 92.17 \\
\hline $\mathrm{Fe}$ & 238.204 & 0.16 & 0.53 & 0.9991 & 118.45 \\
\hline $\mathrm{Mn}$ & 257.610 & 0.02 & 0.07 & 0.9998 & 115.65 \\
\hline $\mathrm{Al}$ & 396.153 & 0.28 & 0.93 & 0.9999 & 88.60 \\
\hline $\mathrm{Mg}$ & 285.213 & 0.11 & 0.37 & 0.9996 & 106.38 \\
\hline $\mathrm{Zn}$ & 206.200 & 0.10 & 0.33 & & 107.85 \\
\hline
\end{tabular}


Table 4. Descriptive statistics of heavy metal concentrations in water samples from the Selangor River.

\begin{tabular}{|c|c|c|c|c|c|c|c|}
\hline \multirow[b]{2}{*}{ Metal } & \multicolumn{5}{|c|}{ Present Study } & \multirow{2}{*}{$\begin{array}{l}\mathrm{MOH} \\
(\mu \mathrm{g} / \mathrm{L})\end{array}$} & \multirow{2}{*}{$\begin{array}{r}\text { NWQS } \\
(\mu \mathrm{g} / \mathrm{L})\end{array}$} \\
\hline & $\begin{array}{c}\text { Maximum } \\
(\mu \mathrm{g} / \mathrm{L})\end{array}$ & $\begin{array}{l}\text { Minimum } \\
(\mu \mathrm{g} / \mathrm{L})\end{array}$ & $\begin{array}{l}\text { Mean } \\
(\mu \mathrm{g} / \mathrm{L})\end{array}$ & $\mathrm{SD}$ & CV (\%) & & \\
\hline $\mathrm{Fe}$ & $3,356.20$ & 947.45 & $1,733.76$ & 767.51 & 40 & 1,000 & 1,000 \\
\hline $\mathrm{Mg}$ & $1,946.47$ & 312.95 & 808.46 & 533.25 & 55 & 150,000 & - \\
\hline $\mathrm{Al}$ & $4,368.84$ & 98.13 & 571.21 & $2,231.49$ & 137 & - & - \\
\hline $\mathrm{Mn}$ & 430.27 & 45.04 & 93.32 & 111.64 & 80 & 200 & 100 \\
\hline $\mathrm{Zn}$ & 235.22 & 53.11 & 85.44 & 62.16 & 58 & 3,000 & 5,000 \\
\hline $\mathrm{Ag}$ & 3.18 & 0.51 & 1.05 & 0.99 & 69 & 50 & 50 \\
\hline $\mathrm{Cd}$ & 1.27 & 0.20 & 0.37 & 0.31 & 66 & 3 & 10 \\
\hline Co & 4.56 & 0.83 & 1.41 & 1.05 & 63 & - & - \\
\hline $\mathrm{Cr}$ & 5.39 & 1.61 & 3.08 & 1.07 & 34 & 50 & 50 \\
\hline $\mathrm{Cu}$ & 35.60 & 6.20 & 9.37 & 8.93 & 70 & 1,000 & 20 \\
\hline $\mathrm{Pb}$ & 20.60 & 0.62 & 3.87 & 5.92 & 70 & 10 & 50 \\
\hline $\mathrm{Ni}$ & 6.87 & 0.72 & 1.15 & 1.79 & 98 & 20 & 50 \\
\hline As & 128.34 & 3.03 & 29.49 & 35.71 & 95 & 10 & 50 \\
\hline
\end{tabular}

SD: standard deviation, CV: coefficient of variance. MOH: Ministry of Health, NWQS: National Water Quality Standard

NSWQS limit. The maximum value of As exceeded both standards. The mean, maximum, and minimum values of $\mathrm{Mg}, \mathrm{Al}, \mathrm{Zn}, \mathrm{Ag}, \mathrm{Cd}, \mathrm{Co}, \mathrm{Cr}, \mathrm{Cu}, \mathrm{Pb}$, and $\mathrm{Ni}$ were well below the NSWQS and MOH limits.

\section{Distribution of Heavy Metals}

Box and whisker plots were drawn to observe the distributions of $\mathrm{As}, \mathrm{Mn}$, and $\mathrm{Fe}$ among the sampling stations (Fig. 2). The concentrations of As, Fe, and Mn varied widely at each station. Fe was the dominant metal in the Selangor River, exceeding the limit of $1,000 \mu \mathrm{g} / \mathrm{L}$ at nearly all sampling stations. The highest concentration of Fe was found at St-9 $(9,741.52 \mu \mathrm{g} / \mathrm{L})$ and the lowest at St-11 $(285.97 \mu \mathrm{g} / \mathrm{L})$. The Fe concentration was significantly high at St-5, St-2, and St-9. It is worth noting that stations St -5 and St-9 are located in the Rawang sub-basin, which is an industrial area cum former tin mining region. On the contrary, station St-2 at the Air Hitam River is surrounded by peatland and palm oil plantation as well as palm oil factories.

Mn exceeded the limit $(200 \mu \mathrm{g} / \mathrm{L})$ at St-5 and St-9. The highest concentration of Mn was found at St-5 $(2,619.36 \mu \mathrm{g} / \mathrm{L})$ and the lowest at St-7 $(9.27 \mu \mathrm{g} / \mathrm{L})$. The possible source of $\mathrm{Mn}$ is industrial estates around the Rawang sub-basin. Arsenic concentration was highest at St-2 $(369.78 \mu \mathrm{g} / \mathrm{L})$ and lowest at St-11 $(2.11 \mu \mathrm{g} / \mathrm{L})$. The highest value of As was found at St-2 located in the former tin mining catchment of Bestari Jaya at the Rantau Panjang sub-basin. The source of As may be mining wastewater from the former tin mining catchment of Bestari Jaya in Peninsular Malaysia. A previous study also reported that
As in the catchment of Bestari Jaya, Peninsular Malaysia, is sourced from the former tin mining area [26]. Bestari Jaya is an old tin mining area. After completion of the mining operations, the environmental consequences are polluted lakes and ponds, and these can be acceded by the substantial impairment to water quality observed in abandoned mining sites worldwide [27]. This indicates that land use of the Selangor River basin could have had negative influences on the metal concentrations of the river water. The Federal Territory of Kuala Lumpur (with $100 \%$ living in urban areas) in Selangor has been the most urbanized state since 1980 [28]. Increases in heavy metal concentration in the river water are due to the continuous increase in the industrial activities and urban expansion along riverbanks in Malaysia [29]. Rapid urbanization and industrialization surrounding the area of the Selangor basin has resulted in an overall increase in heavy metal concentration in the river water. The standard guideline values of heavy metals have had a significant role in ensuring proper management of water resources [30]. Fig. 3 represents the box and whisker plots of the metals, which were well below the standards limits. Elevated concentrations of $\mathrm{Ag}, \mathrm{Al}, \mathrm{Cd}, \mathrm{Co}, \mathrm{Cr}$, $\mathrm{Cu}, \mathrm{Mg}, \mathrm{Ni}, \mathrm{Pb}$, and $\mathrm{Zn}$ were detected at St-5, 6, and 9, although their readings were well below the standards limits. Stations St-5, 6, and 9 are located at Rawang sub-basin, an industrial area within the larger Selangor River basin. Therefore, the increasing trend of heavy metals at those three stations could be due to point sources such as industrial wastes and also non-point sources of mining wastewater from the former tin mining catchment area. 

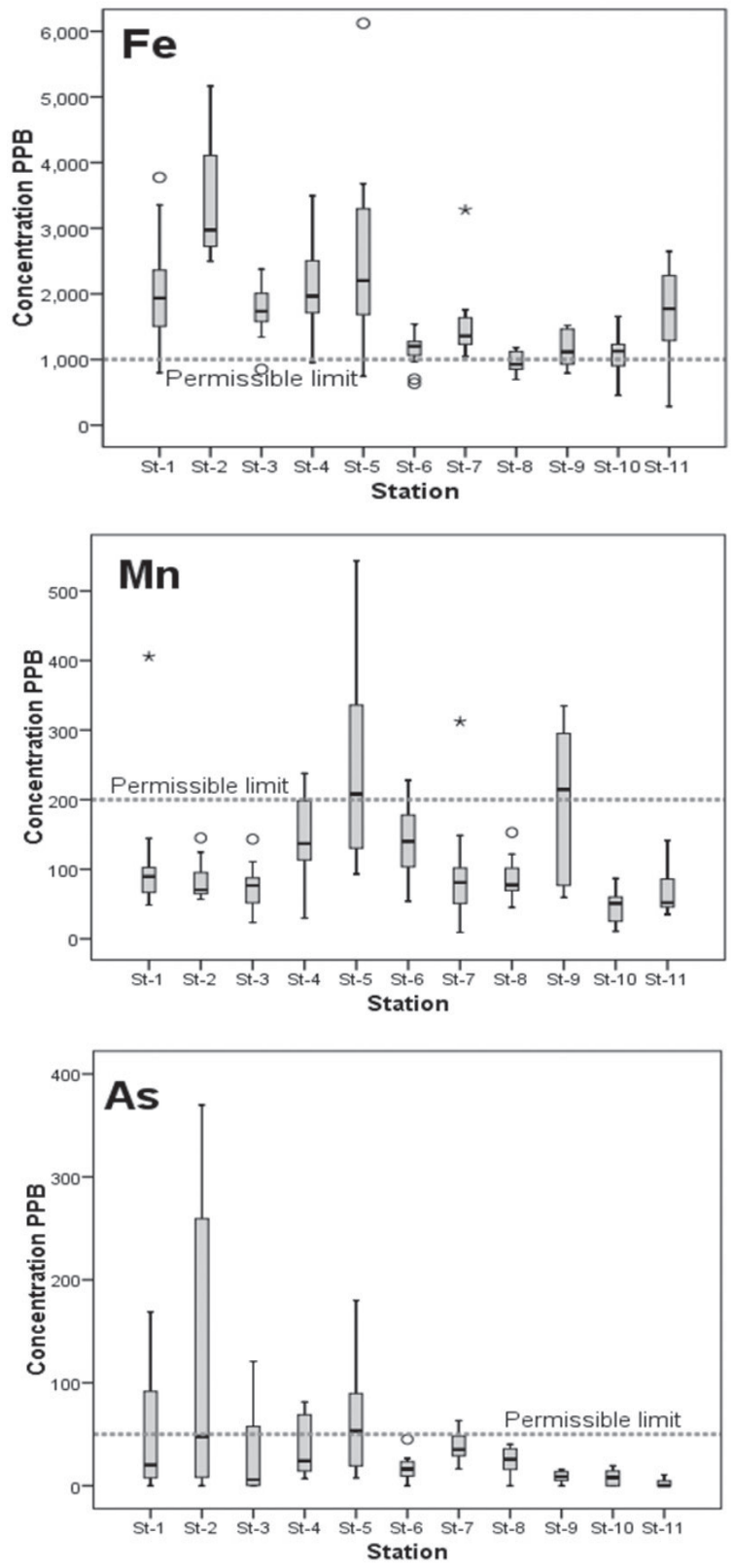

Fig. 2. Box and whisker plots of the distributions of Fe, Mn, and As.

\section{Statistical Analysis}

\section{Pearson Correlation Analysis}

Table 5 shows Pearson's correlation coefficients of studied heavy metals in the Selangor River water. Fe showed a very strong correlation with several heavy metals at $P<0.01$, such as Fe-Mn $(\mathrm{r}=0.80)$, Fe-Mg $(\mathrm{r}=0.86), \mathrm{Fe}-\mathrm{Al}(0.88)$, and $\mathrm{Fe}-\mathrm{Pb}(\mathrm{r}=0.77)$. These indicate that this group of metals may have originated from the same source. Al-Fe-Mg- $\mathrm{Mn}-\mathrm{Pb}$ mainly originated from industrial activities, untreated domestic sewage dumping, and traffic operations. Correlation between metal concentrations and physico-chemical parameters showed turbidity - a finding that triggered a major concern in this study. Concentrations of $\mathrm{Fe}, \mathrm{Mn}, \mathrm{Mg}, \mathrm{Al}, \mathrm{Pb}$, and As in water were positively correlated with turbidity $(\mathrm{r}=0.83, P<0.01$ for Fe; $\mathrm{r}=0.87, P<0.01$ for $\mathrm{Mn} ; \mathrm{r}=0.65$, $P<0.01$ for $\mathrm{Mg} ; \mathrm{r}=0.98, P<0.01$ for $\mathrm{Al} ; \mathrm{r}=0.73, P<0.01$ for $\mathrm{Pb}$; and $\mathrm{r}=0.96, P<0.01$ for As). Turbidity was high at sampling stations St-5, 9, 3, and 4 while elevated metal concentrations were also observed at the same sampling stations. This signifies that the metals do not have a strong bond with the crystal structure of minerals that comprise sediment; thus, dilution due to rain largely affects metal concentration in river water [31]. Furthermore, wastewater from construction sites, industrial effluents, mining activities, agricultural activities, and surface runoff also contribute to high water turbidity, which increases the metal influx into the Selangor River.

\section{Hierarchal Cluster Analysis}

AHCA was applied to evaluate the degree of correlation between various heavy metals and to determine coincidence between the results of the sampling stations. One year (October 2013-September 2014), sampling results of all 13 trace metals were used for AHCA. Dendrograms were obtained using Ward's method, as depicted in Figs. 4(a,b). Thirteen metals formed two clusters where $\mathrm{Ag}-\mathrm{As}-\mathrm{Cd}-\mathrm{Co}-\mathrm{Cr}-\mathrm{Cu}-\mathrm{Mn}-\mathrm{Ni}-$ $\mathrm{Pb}-\mathrm{Zn}$ formed one cluster and $\mathrm{Al}-\mathrm{Fe}-\mathrm{Mg}$ made up another cluster. The degree of association is higher between the elements of the same cluster as opposed to that between the elements of different clusters. The joining of two clusters with a very large linkage distance indicates that each cluster is highly independent [32]. Metals from the same cluster are likely to have originated from common sources. Cluster 1 may be attributed to anthropogenic sources and Cluster 2 to both anthropogenic and natural sources. The AHCA categorized 11 sampling stations into two clusters (Groups 1 and 2) that were statistically significant. St-2, St-9, and St-5 are under Group 1. The similarity among the stations under Group 1 was that concentrations of some heavy metals were high. Elevated concentrations were registered for $\mathrm{As}, \mathrm{Fe}$, and $\mathrm{Mg}$ at station St-2; Al, As, Fe, Mg, Mn, and $\mathrm{Zn}$ at station St-5; and $\mathrm{Co}, \mathrm{Mn}, \mathrm{Ni}$, and $\mathrm{Zn}$ at station St-9. All of these indicate that sampling stations under Group-1 received metals from common sources. Multiple sources widely contributed to the heavy metal load, and these sources include the large-scale inflow from the industries [33]. High concentrations of heavy metals are mostly associated with mining operations that leave the surface water polluted [34-35]. Therefore, the potential contributing sources in Group 1 may be from former tin mining and existing industries. The sampling stations located in the Rawang sub-basin of the Selangor River basin recorded high concentrations of heavy metals. Industrial and former tin mining activities within the Rawang sub-basin increased the metal concentrations within the Selangor River basin. St-1, St-3, St-4, St-6, St-7, St-8, St-10, and St-11 are under Group 2. The similarity among the stations under Group 2 was that the concentration of all studied 
Table 5. Pearson correlation analysis between heavy metals and $\mathrm{pH}, \mathrm{EC}$, turbidity, and temperature.

\begin{tabular}{|c|c|c|c|c|c|c|c|c|c|c|c|c|c|c|c|c|c|}
\hline & $\mathrm{Fe}$ & $\mathrm{Mn}$ & $\mathrm{Mg}$ & $\mathrm{Zn}$ & $\mathrm{Al}$ & $\mathrm{Ag}$ & $\mathrm{Cd}$ & Co & $\mathrm{Cr}$ & $\mathrm{Cu}$ & $\mathrm{Pb}$ & $\mathrm{Ni}$ & As & $\mathrm{pH}$ & $\mathrm{EC}$ & Turbi. & TEMP \\
\hline $\mathrm{Fe}$ & 1 & & & & & & & & & & & & & & & & \\
\hline $\mathrm{Mn}$ & 0.80 & 1 & & & & & & & & & & & & & & & \\
\hline $\mathrm{Mg}$ & 0.86 & 0.64 & 1 & & & & & & & & & & & & & & \\
\hline $\mathrm{Zn}$ & -0.20 & -0.07 & -0.11 & 1 & & & & & & & & & & & & & \\
\hline $\mathrm{Al}$ & 0.88 & 0.92 & 0.67 & -0.22 & 1 & & & & & & & & & & & & \\
\hline $\mathrm{Ag}$ & -0.29 & -0.44 & -0.43 & 0.08 & -0.35 & 1 & & & & & & & & & & & \\
\hline $\mathrm{Cd}$ & 0.00 & 0.12 & -0.10 & -0.06 & 0.16 & -0.26 & 1 & & & & & & & & & & \\
\hline $\mathrm{Co}$ & 0.28 & 0.40 & 0.31 & -0.20 & 0.18 & -0.37 & 0.20 & 1 & & & & & & & & & \\
\hline $\mathrm{Cr}$ & 0.42 & 0.25 & 0.38 & 0.13 & 0.37 & 0.42 & -0.05 & 0.05 & 1 & & & & & & & & \\
\hline $\mathrm{Cu}$ & 0.66 & 0.89 & 0.54 & 0.15 & 0.79 & -0.45 & 0.18 & 0.18 & 0.14 & 1 & & & & & & & \\
\hline $\mathrm{Pb}$ & 0.77 & 0.83 & 0.57 & -0.07 & 0.95 & -0.32 & 0.13 & -0.03 & 0.37 & 0.75 & 1 & & & & & & \\
\hline $\mathrm{Ni}$ & 0.37 & 0.49 & 0.37 & -0.18 & 0.29 & -0.31 & 0.07 & 0.96 & 0.16 & 0.22 & 0.05 & 1 & & & & & \\
\hline As & 0.45 & 0.24 & 0.42 & 0.54 & 0.35 & 0.03 & 0.07 & -0.19 & 0.47 & 0.19 & 0.43 & -0.09 & 1 & & & & \\
\hline $\mathrm{pH}$ & -0.27 & 0.21 & -0.19 & 0.19 & 0.15 & -0.11 & 0.20 & -0.10 & 0.17 & 0.24 & 0.24 & -0.06 & -0.08 & 1 & & & \\
\hline $\mathrm{EC}$ & 0.32 & 0.56 & 0.46 & 0.15 & 0.50 & -0.25 & -0.21 & 0.20 & 0.49 & 0.50 & 0.58 & 0.26 & 0.14 & 0.59 & 1 & & \\
\hline Turbi. & 0.83 & 0.87 & 0.65 & -0.20 & 0.98 & -0.35 & 0.12 & 0.04 & 0.36 & 0.41 & 0.73 & 0.16 & 0.96 & 0.21 & 0.50 & 1 & \\
\hline TEMP & -0.25 & 0.08 & -0.20 & -0.19 & -0.15 & 0.20 & -0.34 & 0.21 & -0.20 & 0.13 & -0.24 & 0.20 & -0.70 & 0.22 & 0.18 & -0.23 & 1 \\
\hline
\end{tabular}

metals appeared to be lower. The potential sources of metals at all stations under Group 2 may possibly be natural. Analysis revealed that the AHCA multivariate technique was able to effectively assess and classify the concentration of heavy metals in the Selangor River basin.

\section{Principal Component Analysis}

PCA was applied to the one-year data of sampled heavy metals set for each station to identify the spatial sources of metals in the Selangor River basin. The variables of this analysis are interrelated with two principal components with the variance in the data set. These are designated on the basis of the eigenvalue, which is higher than one, and the Kaiser criterion. The eigenvalue of a specific factor calculates the variance in all variables that are accounted for by that factor. It explains the importance of the factors associated with the variables. Factors with low eigenvalues contribute little to the explanation of variances in the variables.

In accordance with the eigenvalues $(>1)$, two components were extracted and explained: $51.45 \%$, $56.02 \%, 58.2 \%, 52.34 \%, 69.17 \%, 48.97 \%, 65.52 \%$, $48.86 \%, 77.16 \%, 61.11 \%$, and $50.73 \%$ of the total variance for Stations 1-11, respectively. These variances exhibit sufficient information of data structure. Among those stations, the variance is higher for stations St-2, St-3, St-5, St-7, St-9, and St-10, in which the principal component 1 represents $29 \%, 33 \%, 49 \%, 42 \%, 52 \%$, and
$43 \%$, respectively, having more significant variables than the others. The classification factor loading values of $>0.75,0.75-0.5$, and $0.5-0.3$ are strong, moderate, and weak based on their absolute values [36]. Principal component 1 was characterized by strong loading of $\mathrm{Ni}$ $(\mathrm{r}=0.88), \mathrm{Cu}(\mathrm{r}=0.86), \mathrm{Cr}(\mathrm{r}=0.80)$, and $\mathrm{Zn}(\mathrm{r}=0.70)$ for St-2; $\mathrm{Mg}(\mathrm{r}=0.98), \mathrm{Mn}(\mathrm{r}=0.97), \mathrm{Pb}(\mathrm{r}=0.97)$, Co $(\mathrm{r}=0.96), \mathrm{Ag}(\mathrm{r}=0.91), \mathrm{Cd}(\mathrm{r}=0.90)$, and $\mathrm{Al}(\mathrm{r}=0.88)$ for St-5; Al ( $\mathrm{r}=0.96)$, Ni ( $\mathrm{r}=0.91)$, Co $(\mathrm{r}=0.91)$, Mn $(\mathrm{r}=0.90), \mathrm{Cu}(\mathrm{r}=0.90), \mathrm{Fe}(\mathrm{r}=0.89), \mathrm{Mg}(\mathrm{r}=0.88)$, and $\mathrm{Pb}(\mathrm{r}=0.72)$ for St-9; and $\mathrm{Cd}(\mathrm{r}=0.99), \mathrm{Ni}(\mathrm{r}=0.98), \mathrm{Cr}$ $(\mathrm{r}=0.98), \mathrm{Co}(\mathrm{r}=0.95), \mathrm{Zn}(\mathrm{r}=0.85)$, and $\mathrm{Cu}(\mathrm{r}=0.68)$ for St-10. Other metals in principal component 1 demonstrate low factor loadings, thus indicating their independency within this group.

As for principal component 2, the variance for St2, St-5, St-7, St-9, and St-10 represents 27\%, 20\%, 23\%, $26 \%$, and $18 \%$, respectively. Principal component 2 was characterized by strong loading of $\mathrm{Al}(\mathrm{r}=0.92)$, As $(r=0.87), \mathrm{Mn}(\mathrm{r}=0.67)$, and $\mathrm{Cd}(\mathrm{r}=0.66)$ for St-2; $\mathrm{Zn}(\mathrm{r}=0.94), \mathrm{Cr}(\mathrm{r}=0.89)$, and $\mathrm{Ni}(\mathrm{r}=0.81)$ for $\mathrm{St}-5$; Ni $(\mathrm{r}=0.94), \mathrm{Cr}(\mathrm{r}=0.87), \mathrm{Zn}(\mathrm{r}=0.74)$, and $\mathrm{Cu}(\mathrm{r}=0.62)$ for St-7; $\mathrm{Cr}(\mathrm{r}=0.93), \mathrm{Cd}(\mathrm{r}=0.85), \mathrm{Zn}(\mathrm{r}=0.79)$, and As $(r=0.73)$ for St-9; and $\mathrm{Al}(r=0.69), \mathrm{Mg}(\mathrm{r}=0.69)$, Mn $(r=0.68)$, As $(r=0.59)$ and Ag $(r=0.53)$ for St-10. These analyses classify the heavy metals into two major components that represent the groups of heavy metals and their different sources. Fig. 5 shows that the metals loading patterns of the metals are similar at St-5, St-7, and 

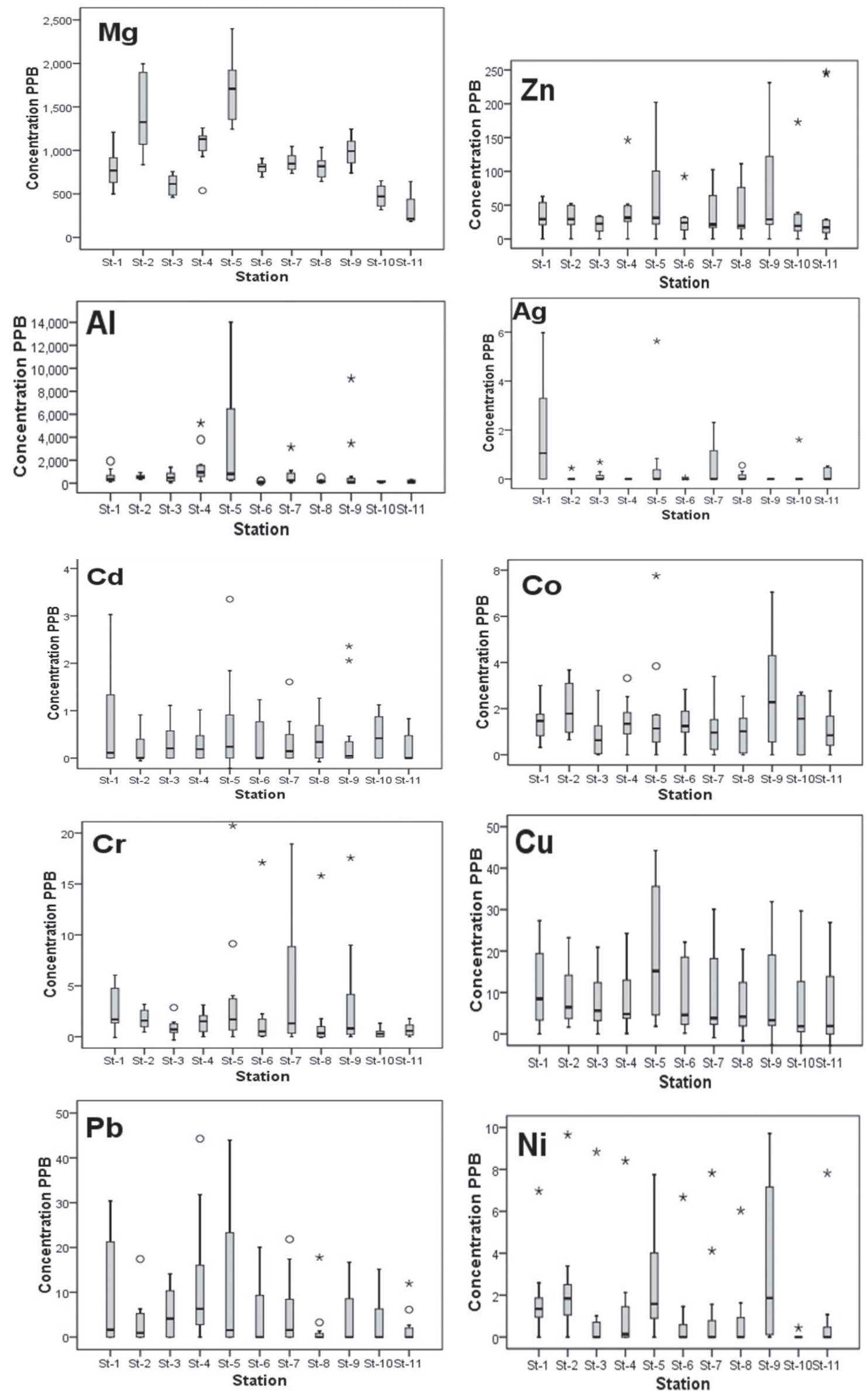

Fig. 3. Box and whisker plots of the distribution of heavy metals that were below standards. 


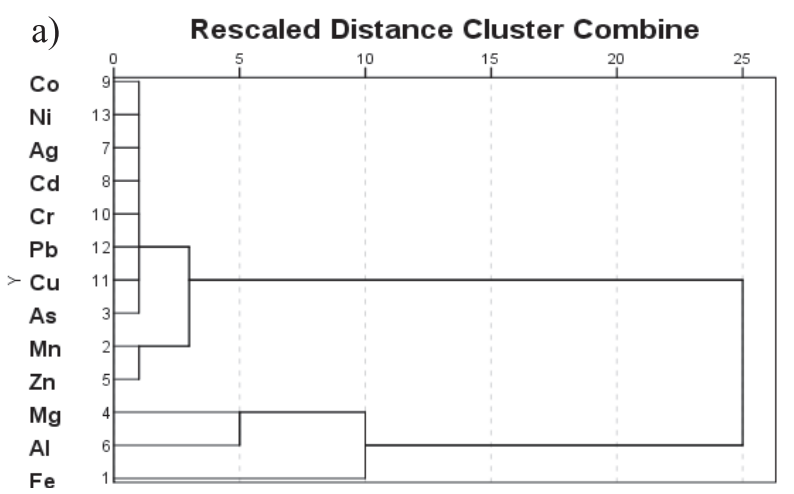

b) Station

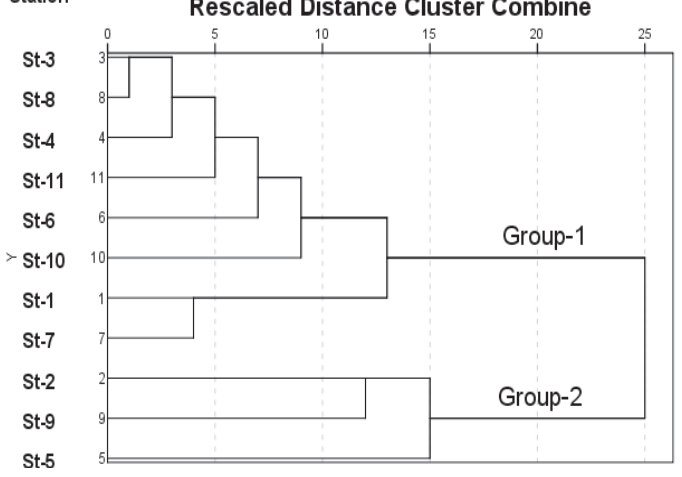

Fig. 4. Dendrogram showing clusters: a) heavy metals parameters and b) sampling station.
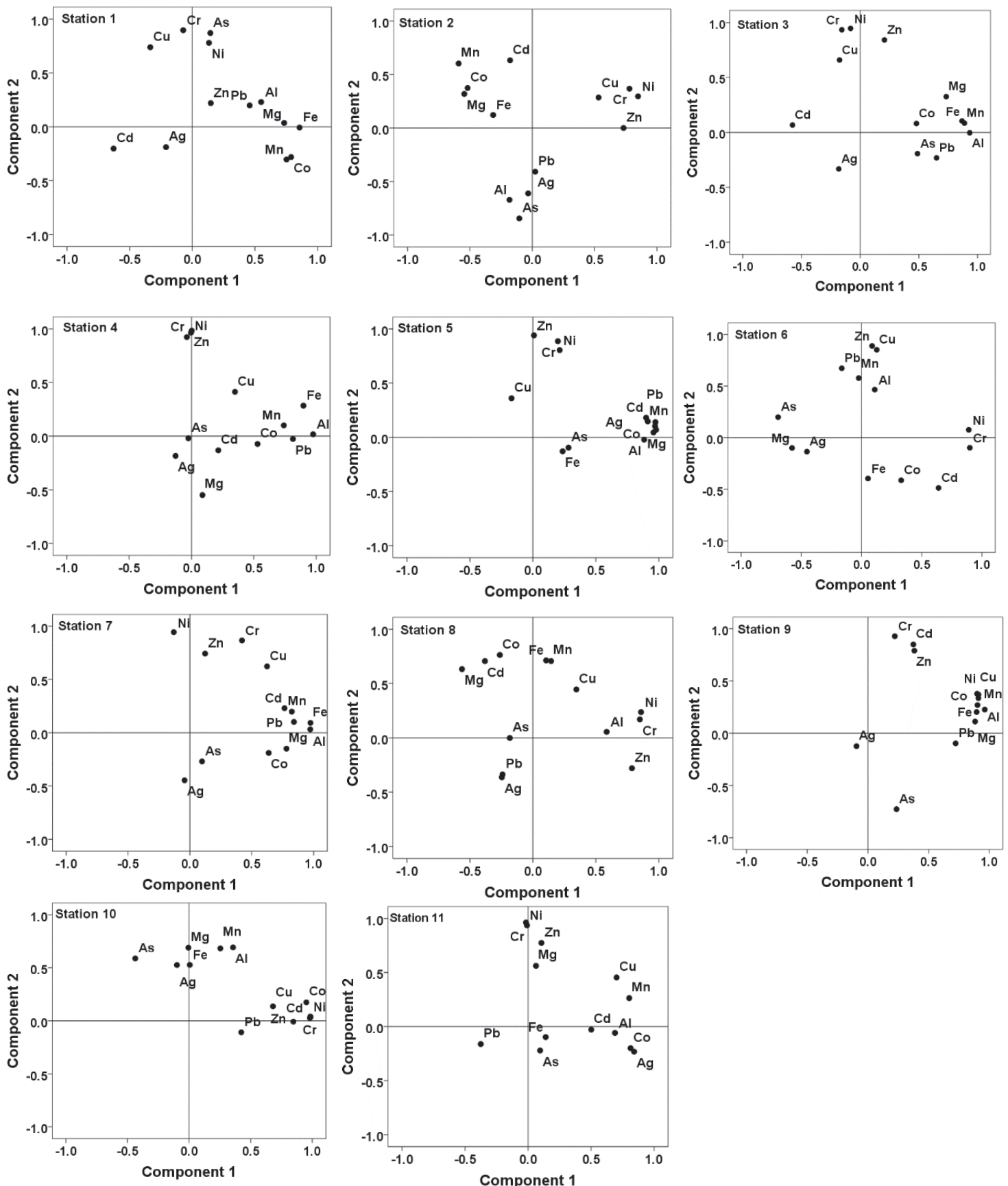

Fig. 5. Principal component analysis plot in rotated space for heavy metals at 11 sampling stations. 


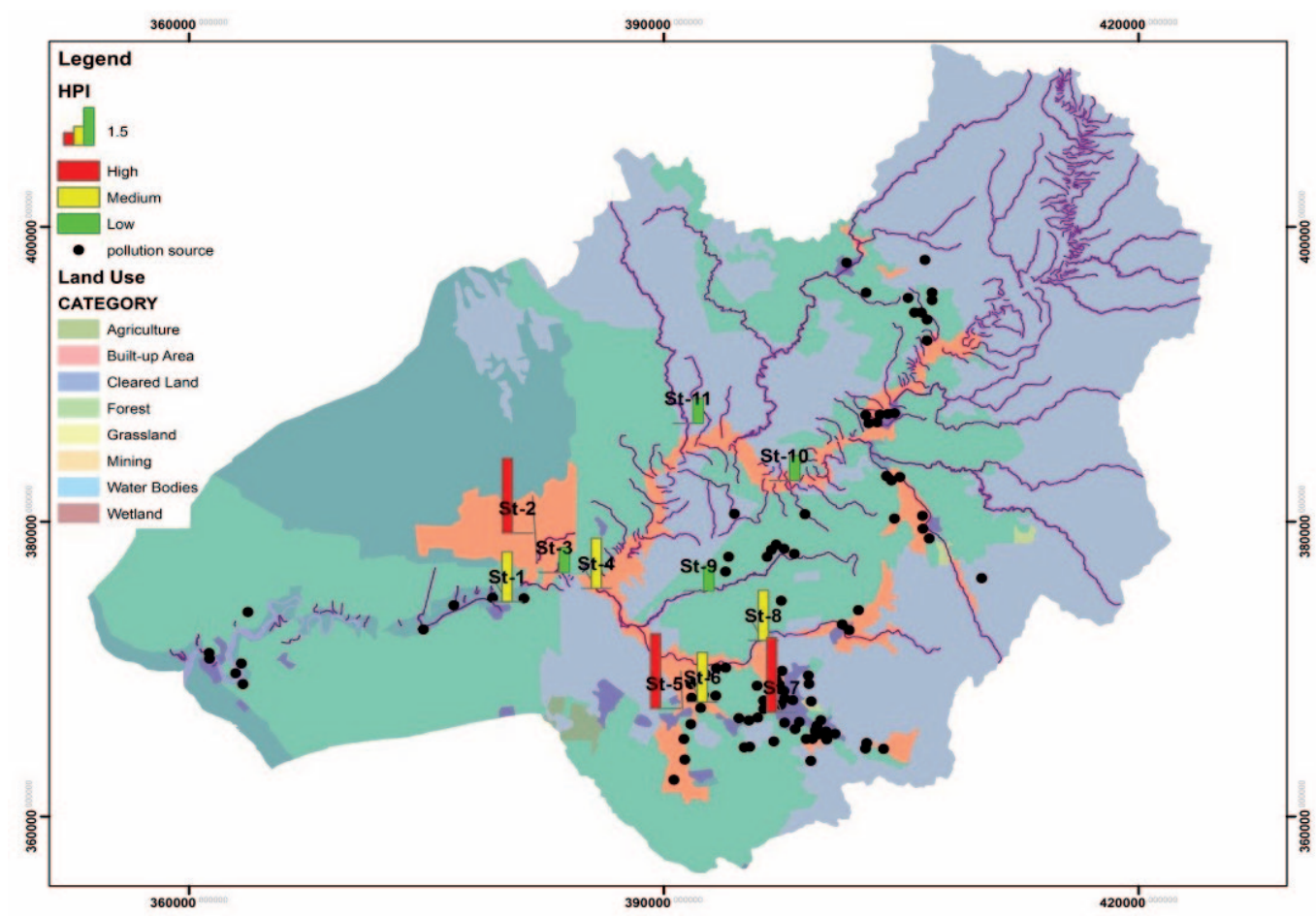

Fig. 6. Land use and point sources map of Selangor River basin and heavy metal pollution index (HPI) variations among the sampling stations.

St-9. The total variance of component 1 was significantly higher at St-2, St-5, St-7, St-9, and St-10 than elsewhere. This concurs with the findings of cluster analysis, which indicates that the sources of heavy metals are common for these stations. These five stations are located in mining, industrial, and agricultural areas that can be seen from the land use map (Fig. 6). Considering such land use, the observed high loading of component 1 metals also implies the possible contribution from mining, industrial, and agricultural activities. Cumulatively, the statistical analyses, correlation, CA, and PCA indicate that St2, St-5, St-7, and St-9 can be clustered together for their common source and controlling factors. These analyses clearly point toward the anthropogenic influence on the Selangor River with respect to the heavy metals being studied. There are many source points along the Rawang sub-basin that discharge their effluents directly into the river. Apart from that, some of the tributaries also pass through old tin-mining belts that in turn carry waste materials into the river. As a result, the waterways have become inadvertently loaded with heavy metals.

\section{Metal Pollution Index Analysis}

In order to assess the risk of metals in Selangor river basin, HPI was calculated based on the studied metal concentration and the NSDWQ. The critical pollution index value is set at 100 . Above this, the metal pollution level should be considered unacceptable for an aquatic ecosystem [37]. The HPI value for Selangor River basin was below the critical value of 100 . However, considering the classes put forward by [38], sampling stations St-2(HPI-48.83), St-5(HPI-57.12), and St-7(HPI-37.13) water quality in regard to metals falls in the high class (HPI $>30)$; St-1(HPI-22.26), St-4(HPI-27.01), St-6(HPI-16.70), and St-8(HPI-29.73) medium class (HPI 15-30); and St-3(HPI-8.72), St-9(HPI-10.44), and St-11(HPI-0.33) low class (HPI $<15)$. The increased HPI was particularly noticeable via the increase of As, Fe, $\mathrm{Mg}, \mathrm{Mn}$, and $\mathrm{Zn}$. A similar increasing trend was observed near the Rawang sub-basin industrial zone adjacent to the river. Not surprisingly, that potentially contributed to the increase in heavy metal pollution within the local river. Admittedly, the HPI variation was more influenced by the location of sampling stations. HPI values in the Selangor River basin showed good agreement with the number of point sources and non-point sources (land use map) in surrounding sub-basins, indicating that HPIs were also directly related to human and land-based activities (Fig. 6). Hence, it can be inferred that the combined influence of corresponding heavy metals on river water quality is alarming. This is consequential to the mining and industrial activities near some of the sites that can be visualized while evaluating the HPI for each location.

\section{Conclusions}

Concentrations of Ag, Al, As, Cd, Co, Cr, Cu, Fe, Mg, $\mathrm{Mn}, \mathrm{Ni}, \mathrm{Pb}$, and $\mathrm{Zn}$ were studied to elucidate the potential of heavy metal contamination across the Selangor River basin. As, Fe, and Mn exceeded the standard limits, 
while the concentrations of $\mathrm{Ag}, \mathrm{Al}, \mathrm{Cd}, \mathrm{Co}, \mathrm{Cr}, \mathrm{Cu}, \mathrm{Mg}$, $\mathrm{Ni}, \mathrm{Pb}$, and $\mathrm{Zn}$ were well below the Malaysian NSDWQ and $\mathrm{MOH}$ limits. Based on the calculated values of HPI, the Selangor River was not critically polluted. However, high classes of HPIs were registered at St-2, St-5, and St-7. The standard limits for Fe were surpassed at St-2 and St-5, and for Mn at St-5 and St-9. Statistical analyses showed good agreement between those two, which provided evidence to seek and identify the sources of heavy metals.

The elevated concentrations of As, Fe, and Mn may be due to pollution from discharge point sources, namely the neighbouring industrial zones. Alternatively, they could have risen from non-point sources, such as the former tinmining areas. Collectively, these increase the incidence of pollution across the Rawang sub-basin within the study area. Besides originating from the geology of the river bed and catchment area, the excess metal load in the Selangor River may also be attributed to human activities such as discharge of mining wastes, industrial effluents, and municipal wastes. Although the heavy metal level in the Selangor River is not alarming at present, the elevated concentrations of certain metals could pose a worrying threat in the future due to their accumulative nature and toxicity effects on living organisms.

This study provides an important message about the environmental risks of heavy metal contamination in the tainted Selangor River by making comparisons to standard water quality guidelines. Endangered locations that are under threat were identified by statistical analysis and spatial distributions of heavy metals along the Selangor River. The study findings can act as objective reference points for future research geared toward protecting the Selangor River from heavy metal pollution.

\section{Acknowledgements}

The authors are grateful for the financial support of the University Malaya Research Grants (FL026-2012D, FL001-13SUS, and RP017C-15SUS). We would also like to acknowledge the Water Research Center of the University of Malaya, the Malaysian Ministry of Education (MOE), and the JSPS-Asian CORE Program for their support. We also would like to thank the reviewers for their valuable suggestions that have led to substantial improvement of the article.

\section{References}

1. ARNOUS M.O., HASSAN M.A. Heavy metals risk assessment in water and bottom sediments of the eastern part of Lake Manzala, Egypt, based on remote sensing and GIS. Arab J Geosci, 1, 20, 2015.

2. P. SZYCZEWSKI, J. SIEPAK P.N., SOBCZYŃSKI T. Research on Heavy Metals in Poland. Polish J of Environ Stud., 18, 755, 2009.

3. TANG J., HUANG Z., PAN X.-D. Exposure assessment of heavy metals $(\mathrm{Cd}, \mathrm{Hg}$, and $\mathrm{Pb})$ by the intake of local foods from Zhejiang, China. Environ Geochem Hlth., 36, 765, 2014.

4. SHA LOU S.L., CHAOMENG DAI, AN TAO BT, GANGFENG M.A., RSC, CHALOV SR. Heavy Metal Distribution and Groundwater Quality Assessment for a Coastal Area on a Chinese Island. Pol J Environ Stud, 26, 733, 2017.

5. ADEPOJU M., ADEKOYA J. Heavy metal distribution and assessment in stream sediments of River Orle, Southwestern Nigeria. Arab J Geosci, 7, 743, 2014.

6. SHIKAZONO N., TATEWAKI K., MOHIUDDIN K., NAKANO T., ZAKIR H. Sources, spatial variation, and speciation of heavy metals in sediments of the Tamagawa River in Central Japan. Environ Geochem Hlth, 34, 13, 2015.

7. KAMARUZZAMAN B.Y., WAZNAH A.S., NURULNADIA M.Y. Physico-chemical characteristics and dissolved trace metals in the Pahang River estuary,Malaysia. . Oriental Journal of Chemistry. 27, 397, 2011.

8. YAP C.K., PANG B.H. Assessment of $\mathrm{Cu}, \mathrm{Pb}$, and $\mathrm{Zn}$ contamination in sediment of north western Peninsular Malaysia by using sediment quality values and different geochemical indices. Environ Monit Assess, 183, 23, 2011.

9. LIM W.Y., ARIS A.Z., PRAVEENA S.M. Application of the chemometric approach to evaluate the spatial variation of water chemistry and the identification of the sources of pollution in Langat River, Malaysia. Arab J Geosci, 6, 4891, 2013.

10. WANG J., LIU R.H., YU P., TANG A.K., XU L.Q., WANG JY.. Study on the pollution characteristics of heavy metals in seawater of Jinzhou Bay. Procedia Environmental Sciences 13, 1507, 2012.

11. IDRISS A.A., AHMAD A.K. Concentration of selected heavy metals in water of theJuru River, Penang, Malaysia. . African Journal of Biotechnology, 11, 8234, 2012.

12. DOE. Malaysia Environmental Quality Report. Kuala Lumpur, Malaysia: Department of Environment (DOE), Ministry of Natural Resources and Environment. 2009.

13. ZULKIFLI S.Z., MOHAMAT-YUSUFF F., ARAI T., ISMAIL A., MIYAZAKI N. An assessment of selected trace elements in intertidal surface sediments collected from the Peninsular Malaysia. Environ Monit Assess, 169 (1-4), 457, 2010.

14. YAP C.K., CHEE M.W., SHAMARINA S., EDWARD F.B., CHEW W., TAN S.G. Assessment of surface water quality in the Malaysian coastal waters using multivariate analyses. Sains Malaysiana 40, 1053, 2011.

15. MOHAMMED SEYAM, OTHMAN F. Long-term variation analysis of a tropical river's annual streamflow regime over a 50-year period. Theoretical and Applied Climatology, 121, 71, 2015.

16. DID. Selangor river basin management plan 2007-2012. Kuala Lumpur, Malaysia 2007.

17. SAKAN S., DEVIĆ G., RELIĆ D., ANĐELKOVIĆ I., SAKAN N., ĐORĐEVIĆ D. Evaluation of sediment contamination with heavy metals: the importance of determining appropriate background content and suitable element for normalization. Environ Geochem Hlth, 37, 97, 2015.

18. LEI ZHAO, DONG MI, YIFU CHEN, LUO WANG, SUN Y. Ecological risk assessment and sources of heavy metals in sediment from Daling River basin. Environ Sci Pollut Res, 22, 5975, 2015.

19. MOHAMAD ALI FULAZZAKY, TENG WEE SEONG, MOHD IDRUS MOHD MASIRIN. Assessment of Water 
Quality Status for the Selangor River in Malaysia,Water Air Soil Pollut, 205, 63, 2010.

20. ASHRAF MA, J. MAAH M, YUSOFF I. Chemical Speciation and PotentialMobility of HeavyMetals in the Soil of Former TinMining Catchment. The ScientificWorld Journal. 11, 2012.

21. PRAVEENA S.M., ABDULLAH M.H., BIDIN K., ARIS A.Z. Understanding of groundwater salinity using statistical modeling in a small tropical island, East Malaysia. The Environmentalist, 31, 279, 2011.

22. OSMAN R., SAIM N., JUAHIR H., M A. Chemometric application in identifying sources of organic contaminants in Langat river basin. Environ Monit Assess. 184, 1001, 2012.

23. NAMAGHI H.H., KARAMI G.H., SAADAT S. A study on chemical properties of groundwater and soil in ophiolitic rocks in Firuzabad, east of Shahrood, Iran: with emphasis to heavy metal contamination. Environ Monit Assess. 176, 573, 2011.

24. HARUN S., ABDULLAH, M.H. M, M. F, A.H., JIMMY E.O. Water Quality Study of Four Streams withinMaliau Basin Conservation Area, Sabah, Malaysia. JTropical Biol Conservation, 6, 109, 2010.

25. Water Quality Standards for Malaysia. "National Standard for Drinking Water Quality (NSDWQ)," 2004.

26. ASHRAF M.A., MAAH M.J., GHARARIBREZ IYAM. Speciation of heavy metals in the surface waters of a former tin mining catchment. Chemical Speciation and Bioavailability, 24 (1), 401, 2012.

27. KAH HIN LOW, ISA BABA KOKI, HAFIZAN JUAHIR, AZMAN AZID, SHIMA BEHKAMI, RABIA IKRAM, HAMISU ALIYU MOHAMMED, SHARIFUDDIN MD. ZAIN. Evaluation of water quality variation in lakes, rivers, and ex-mining ponds in Malaysia (review), Desalination and Water Treatment, 2016, 1, 2016.

28. ABDUL RAHMAN HASAN, PREMA LETHA NAIR. Urbanisation and Growth of Metropolitan Centres in Malaysia, Malaysian Journal of Economic Studies 51 (1), 87, 2014.

29. KAH HIN LOW, ISA BABA KOKI, HAFIZAN JUAHIR, AZMAN AZID, SHIMA BEHKAMI, RABIA IKRAM, HAMISU ALIYU MOHAMMED, SHARIFUDDIN MD. ZAIN. Evaluation of water quality variation in lakes, rivers, and ex-mining ponds inMalaysia (review), Desalination and Water Treatment, 2016, 1, 2016.
30. BULAT NADMITOV, SEONGJIN HONG, SANG IN KANG, JANG MIN CHU, BAIR GOMBOEV, LUNTEN JANCHIVDORJ,. Large-scale monitoring and assessment of metal contamination in surface water of the Selenga River Basin (2007-2009). Environ Sci Pollut Res, 22, 2856, 2015

31. TAVAKOLY SANY B., SULAIMAN A.H., MONAZAMI G,H., SALLEH A. Assessment of Sediment Quality According To Heavy Metal Status in the West Port of Malaysia. World Academy of Science, Engineering and Technology, 50, 2011.

32. YALCIN M.G, TUMUKLU A., SONMEZ M.A., ERDAG D.S. Application of multivariate statistical approach to identify heavy metal sources in bottom soil of the Seyhan River (Adana), Turkey. Environ Monit Assess, 164, 311, 2010.

33. SEYEDEH BELIN TAVAKOLY SANY, AISHAH SALLEH, MAJID REZAYI, NAGHMEH SAADATI, LEILA NARIMANY, GHAZALEH MONAZAMI TEHRANI, Distribution and Contamination of Heavy Metal in the Coastal Sediments of Port Klang, Selangor, Malaysia, Water Air Soil Pollut, 224, 1476, 2013.

34. LI Z., MA Z., VAN DER KUIJP T.J., UAN Z., HUANG L. A review of soil heavy metal pollution from mines in China: Pollution and health risk assessment, Sci. Total Environ. 843, 2014.

35. NING L., LIYUAN Y., JIRUI D., XUGUI P. Heavy metal pollution in surface water of Linglong gold mining area, China, Proc. Environ. Sci. 10, 914, 2011.

36. NAIR. I.V, K. SINGH, M. ARUMUGAM, AND KG, D. CLARSON. Trace metal quality of Meenachil River at Kottayam, Kerala (India) by principal component analysis. World Applied Sciences Journal, 9, 1100, 2010.

37. REZA R., SINGH G. Heavy metal contamination and its indexing approach for river water Int J Environ Sci Tech, 7, 785, 2010.

38. EDET A., OFFIONG O. Evaluation of water quality pollution indices for heavy metal contaminationmonitoring. Astudy case from Akpabuyo-Odukpani area, Lower Cross River Basin (southeastern Nigeria). GeoJournal. 57, 295, 2002. 
